\title{
Grass valorisation and muscular characteristics of blonde d'Aquitaine steers
}

\author{
Anne LISTRAT ${ }^{\mathrm{a} *}$, Brigitte PICARD ${ }^{\mathrm{a}}$, Rolland JAILLER ${ }^{\mathrm{a}}$, \\ Hervé Collignon ${ }^{\mathrm{a}}$, Jean-Rémy PeCCATTE ${ }^{\mathrm{c}}$, Didier MiCOL ${ }^{\mathrm{b}}$, \\ Yves GeAY ${ }^{\mathrm{a}}$, Domnique DozIAS ${ }^{\mathrm{c} * *}$ \\ ${ }^{a}$ INRA, Unité de Recherches sur les Herbivores, Équipe Croissance et Métabolismes du Muscle, \\ Theix, 63122 Saint-Genès-Champanelle, France \\ b INRA, Unité de Recherches sur les Herbivores, Équipe Systèmes de Production, \\ Theix, 63122 Saint-Genès-Champanelle, France \\ c INRA, Domaine Expérimental Animal, Borculo, 61310 Exmes, France
}

(Received 27 September 1999; accepted 8 November 2000)

\begin{abstract}
The blonde d'Aquitaine breed, the males of which are traditionally raised as young steers in intensive systems, is spreading beyond its region of origin. In pasture regions these males could be introduced into more extensive grazing systems. The purpose of this study is to assess the capability of these animals to valorise forage resources and also the characteristics of the carcasses produced and of the muscles concerned when considering meat tenderness. The study used young weaned bulls reared as beef animals and slaughtered at 33 months of age $(n=22$ and 24). These beef animals use 2 very different types of pasture during the pasturing seasons (April-November). During the first winter period of rearing the Blonde d'Aquitaine show a lower ingestion of forage (5.8 kg dry matter $\cdot 100 \mathrm{~kg}^{-1}$ life weight vs. $7.5 \mathrm{~kg}$ dry matter $\cdot 100 \mathrm{~kg}^{-1}$ life weight) and lower growth than the Charolais $\left(1150 \mathrm{~g} \cdot \mathrm{d}^{-1}\right.$ vs. $\left.1400 \mathrm{~g} \cdot \mathrm{d}^{-1}\right)$. At pasture, the activity of the animals is similar (380 minutes at pasture, 52 bites per minute for speed of ingestion). At slaughter, at the same body weight $(695 \mathrm{~kg})$, the Blonde d'Aquitaine have a greater weight of muscle $(+9 \%, 335 \mathrm{~kg}$ of muscle vs. $308 \mathrm{~kg})$. The Blonde d'Aquitaine have a more glycolytic muscular metabolism $(1497 \mu \mathrm{mol}$ $\mathrm{min}^{-1} \cdot \mathrm{g}^{-1}$ vs. $\left.1351 \mu \mathrm{mol} \cdot \mathrm{min}^{-1} \cdot \mathrm{g}^{-1}\right)$, a higher proportion of fast, IIB fibers (63.6\% vs. 58.8\%) and less collagen $\left(3.7 \mu \mathrm{g}\right.$ d'OH-prol-mg ${ }^{-1}$ of DM vs. $5.2 \mu \mathrm{g} \mathrm{d}$ 'OH-prol-mg ${ }^{-1}$ of DM). These results show that animals of blonde d'Aquitaine breed provide a good valorisation of forage and grass and that under these breeding conditions, they produce muscles with favourable characteristics for production of tender meat.
\end{abstract}

blonde d'Aquitaine / Charolais / grass / muscle fibers / collagen

\footnotetext{
* Correspondence and reprints e-mail: listrat @ clermont.inra.fr

** e-mail: Dominique.Dozias @ rennes.inra.fr
} 
Résumé - Valorisation de l'herbe et caractéristiques musculaires en race blonde d'Aquitaine. La race blonde d'Aquitaine dont les mâles sont traditionnellement exploités en jeunes bovins intensifs connaît une extension hors de son berceau d'origine. Dans les zones herbagères ces mâles pourraient être introduits dans des systèmes plus extensifs. Le but de cette étude a été de préciser l'aptitude de ces animaux à valoriser des ressources fourragères ainsi que les caractéristiques des carcasses produites et celles des muscles impliquées notamment dans la tendreté de la viande. L'étude de ce génotype tardif, a été réalisée en référence au génotype charolais mieux connu. L'expérience a porté sur des animaux conduits en bœufs de 33 mois. Durant la période hivernale initiale de croissance, les Blonds d'Aquitaine ont eu des niveaux d'ingestion de fourrages $\left(5,8 \mathrm{~kg} \mathrm{MS} \cdot 100 \mathrm{~kg}^{-1} \mathrm{de}\right.$ poids vif vs. 7,5 kg MS $100 \mathrm{~kg}^{-1}$ de poids vif) et des niveaux de croissance plus faibles que les Charolais (1 $150 \mathrm{~g} \cdot \mathrm{j}^{-1}$ vs. $\left.1400 \mathrm{~g} \cdot \mathrm{j}^{-1}\right)$. Au pâturage, les activités des animaux (temps à pâturer, vitesse d'ingestion...) ont été comparables (380 minutes au pâturage, 52 bouchées par min pour la vitesse d'ingestion). À l'abattage, à même masse corporelle $(695 \mathrm{~kg})$, les Blonds d'Aquitaine ont eu un poids de muscle plus élevé $(+9 \%, 335 \mathrm{~kg}$ de muscle vs. $308 \mathrm{~kg})$. Le muscle des Blonds d'Aquitaine présente un métabolisme glycolytique nettement plus important $\left(1497 \mu \mathrm{mol} \cdot \mathrm{min}^{-1} \cdot \mathrm{g}^{-1} \mathrm{vs.} 1351 \mu \mathrm{mol} \cdot \mathrm{min}^{-1} \cdot \mathrm{g}^{-1}\right)$, une proportion de fibres rapides, II B $(63,6 \%$ vs. $58,8 \%)$ plus élevée et une teneur en collagène inférieure (3.7 $\mu \mathrm{g}$ d'OH-prol- $\mathrm{mg}^{-1}$ de matière sèche vs. $5.2 \mu \mathrm{g} \mathrm{d}$ 'OH-prol $\cdot \mathrm{mg}^{-1}$ de matière sèche). En conclusion, les Blonds d'Aquitaine valorisent donc efficacement les fourrages et l'herbe et produisent des muscles dont les caractéristiques sont favorables à l'obtention d'une viande tendre.

\section{blonde d'Aquitaine / Charolais / herbe / fibres musculaires / collagène}

\section{INTRODUCTION}

The male calves of the blonde d'Aquitaine (BA) breed which are not kept for reproduction are mainly sold thin, between 3 and 5 months, in order to be fattened for the main part as bull calves, in Italy [10]. The spread of this breed beyond the area where it originated, notably to areas with more pasture, could lead beef farmers to introduce males into a far more extensive rearing system similar to those proposed for other meat breeds such as the charolais breed. Only one study has been made, by Gillard et al. [14], based on steers crossbred from BA bulls and Limousin, charolais and maine-anjou cows. This study showed that these crossbred animals, slaughtered at about 30 months after 2 pasture seasons showed growth between weaning and slaughter similar to those of charolais steers of the same age, but at slaughter had better muscle yield. However, we have no information concerning the muscular characteristics of steers of this breed. Only whole males raised as young bulls in intensive production systems are known to give a carcass with little fat, with a high carcass and muscle yield [10] and meat that is light in colour, particularly tender and keeps without any great loss of exsudate [22].

So the purpose of this study was to learn more about the BA breed with respect to 30-month-old steer production: its ability to make good use of pasture as expressed by its grazing behaviour and performance at pasture, the characteristics of the carcasses and muscles concerned notably for meat tenderness. The better-known charolais breed was used as a control.

\section{MATERIALS AND METHODS}

\subsection{Animals and experimental system}

Forty-six BA $(n=22)$ and charolais $(n=24) 8$-month-old male calves were reared to produce 33-month-old steers at the Pin au Haras (Orne) INRA property and allocated according to a factorial plan ( 2 breeds $\times 2$ types of pasture land) in order to learn more about the BA breed reaction to the quality of pasture. The 2 types of 
meadows given during the 2 grazing periods were a perennial rye grass and wild white clover meadow corresponding to a very good pasture and a high fescue meadow, deliberately not conducted at optimum, simulating a mediocre grazing resource.

Castration took place at the age of 9 months. The animals were raised untethered in sheds for two winters (between 8 and 12 months, then between 20 and 24 months) followed by 2 periods of pasture (between 12 and 20 months, then between 24 and 29 months) and followed by a finishing stage at the trough (between 29 and 33 months) (Fig. 1). During the first winter, they were fed ad libitum with a diet based on hay and corn silage, i.e. $85 \%$ forage, completed by rape seed oil cake. During the 2 nd winter, they were fed ad libitum with a $100 \%$ grass silage diet. During finishing, the animals were fed, ad libitum, with corn silage completed by rape seed oil cake. The 2 breeds were conducted together to graze on 2 types of grazing resource and were kept separately in the sheds. Slaughter was programmed at the same weight for each breed, in the region of 33 months.

\subsection{Zootechnical measurements}

\subsubsection{Animal growth and fattening mark}

Animal growth was measured by one weighing every two weeks and by weighing for 2 consecutive days from the moment they went to graze and from the moment they entered the cowshed, then at the beginning and the end of the finishing period. These weighing operations were carried out at fixed hours and two or three days after the return to a trial pasture plot. During the finishing period, the animals were given a fattening mark assessed by palpation at rib level and at tail level according to the chart defined by Agabriel et al. [1].

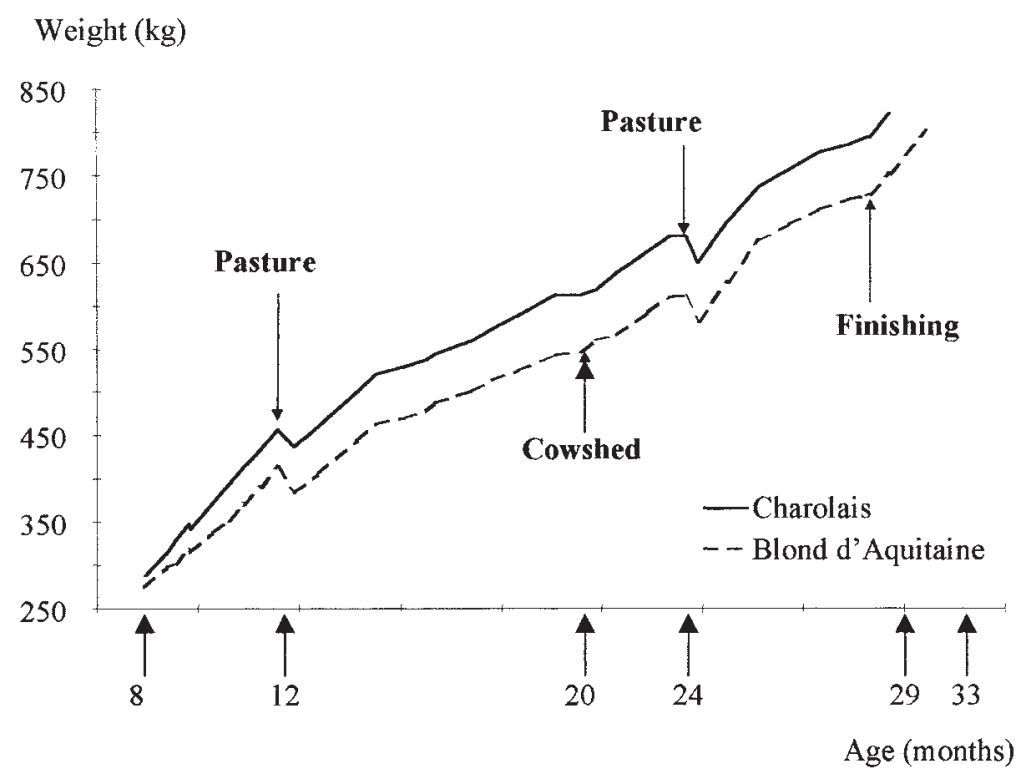

Figure 1. Evolution in weight of blonde d'Aquitaine and charolais steers (from age 8 months to slaughter). 


\subsubsection{Trough feeding}

The quantities of food distributed (maize silage, hay, rape seed oil cake) were measured daily per portion. Uneaten food was removed and weighed 3 times a week. The dry matter content of food was measured 3 times a week for forage and once a week for concentrates. Samples for assay of dry matter (DM) content of silage were ground and analysed to determine the mineral matter, total nitrogen and crude fibre content. Digestibility of silage during the distribution period was measured using 6 castrated male sheep kept in metabolism crates and fed ad libitum. Feed value of forage was determined on the basis of calculations developed by INRA [19] and expressed in $g$ of protein digestible in the small intestin allowed by the energy level of the diet (PDIE) and the nitrogen level (PDIN) and in milk feed units (UFL) or meat feed units (UFV) according to whether the forage permitted growth rates above or below $1000 \mathrm{~g} / \mathrm{d}$, which were the growth rates necessary for managing the animals. The bulk represented by the ration was estimated on the basis of tables drawn up by INRA [19]. Feed values are given in Table I.

\subsubsection{Ability to graze}

Activity at pasture was analysed by assessing the behaviour of the steers and the number of bites per minute $[8,9,12,13]$. Behaviour was measured between sunrise and sunset, by counting every 5 minutes the number of animals for each activity: "animal lying down, animal moving, various activities" (drinking; bulling, etc.) and animal grazing, that is, with its head down to the grass. These measurements were carried out for each of the 2 breeds on the 2 types of pasture, giving 4 sets of measurements per day of observation. These days were repeated for each cycle in use of the pastures, the day after the animals were admitted to a plot then the day before they left it. The bite frequency was measured at 1 to 3 hours after sunrise when the animals were all actively and intensively grazing, by individually counting the number of bites over short periods of between 30 and $150 \mathrm{sec}-$ onds. Six animals per experimental group were observed for 4 to 5 minutes. During the two seasons at pasture each group of animals was observed 16 times between April and October. During the second year however this period was shorter due to a

Table I. Chemical composition and nutritional value.

\begin{tabular}{|c|c|c|c|c|c|c|c|c|c|}
\hline & \multicolumn{4}{|c|}{$\begin{array}{l}\text { Organic components } \\
\text { (\% of DM) }\end{array}$} & \multicolumn{2}{|c|}{ Energy value } & \multirow{2}{*}{\multicolumn{2}{|c|}{$\frac{\text { PDIN PDIE }}{(\mathrm{g})}$}} & \multirow{2}{*}{$\begin{array}{l}\text { Bulk } \\
\text { BBU }\end{array}$} \\
\hline & $\mathrm{DM}$ & MM & $\mathrm{TN}$ & $\mathrm{CF}$ & UFL & UFV & & & \\
\hline Maize silage & 33 & 4.7 & 8.2 & 16.5 & & 0.87 & 42 & 65 & 1.09 \\
\hline Grass silage & 25 & 9.6 & 11.8 & 28.8 & 0.77 & & 64 & 53 & 1.33 \\
\hline Hay & 85 & 9.2 & 14.8 & 29.5 & & 0.71 & 92 & 90 & 1.03 \\
\hline Rape seed oil cake & 89 & 7.7 & 39.1 & 12.9 & & 1.00 & 253 & 154 & \\
\hline
\end{tabular}

DM: Dry Matter.

MM: Mineral Matter.

TN: Total Nitrogen content.

CF: Crude Fibre.

UFL or UFV: Net energy for maintenance and gain. Values expressed in milk feed units (Unités Fourragères Lait) or in meat feed units (Unités Fourragères Viande).

Proteins truly Digestible in the small Intestine allowed by the Nitrogen (PDIN) or energy (PDIE) level [19].

BBU: Bovine Bulk Unit. 
dry summer requiring the animals to be returned to the cowshed earlier for fattening.

\subsubsection{Body characteristics at slaughter}

The animals were slaughtered at the experimental slaughter house at the INRA Clermont-Ferrand/Theix (63) centre. Three animals for each breed and representative of their group were slaughtered at the beginning of the finishing period. The purpose of this early slaughter was to assess the animals at the end of the pasture period. The different body parts (elements of the fifth quarter [kidney, heart, digestive tractus], hot and chilled carcass) were weighed. In addition dissection of the sixth rib, associated with the carcass weight and measurement of the fatty deposits of the 5th quarter, allowed an estimation of the composition of the carcass based on regression equations established by Robelin and Geay [28].

\subsection{Measurements of the muscle characteristics (fibre types and collagen)}

Semitendinosus (ST) muscle samples were taken one hour after slaughter for measurement of the fibre types and collagen characteristics.

\subsubsection{Proportion and muscle fibre size}

Ten $\mu \mathrm{m}$ thick serial sections were cut perpendicular to the muscle fibres on a cryostat at $-25^{\circ} \mathrm{C}$. The sections were stained with azorubine to define histological architecture of the muscle and to measure fibre proportion and diameter.

\subsubsection{Determination of the fibre contractile type}

The contractile type of the fibres was determined by the method of Guth and Samaha [16] adapted to bovine muscle. The myofibrillar ATPase activity was determined after acid pre-incubation of sections at $\mathrm{pH} 4.2$ for $15 \mathrm{~min}$. The metabolic type of fibres was determined as succinate dehydrogenase (SDH) activity [23]. Fibres were identified according to ATPase and SDH reactions and classified, according to Peter et al. [24], as slow oxidative (SO), fast oxidative glycolytic (FOG) or fast glycolytic (FG).

The percentage of each type of fibre and their mean surface areas were measured in two randomly selected areas on serial sections with an image analysis software program (Visilog). An average of 200 fibres was analysed on each serial section.

\subsubsection{Measurement of enzyme activities}

The muscle samples were ground and homogenized in $140 \mathrm{mM}$ sucrose and $50 \mathrm{mM}$ triethanolamine buffer $(\mathrm{pH} 7.5)$ and centrifuged at $6000 \mathrm{~g}$ for $15 \mathrm{~min}$ at $4{ }^{\circ} \mathrm{C}$. Enzyme activities were measured in the supernatant. Anaerobic glycolytic metabolism was assessed by lactate dehydrogenase (LDH, EC 1. 1. 1. 27) activity in the transformation of pyruvate into lactate [2]. Aerobic oxidative metabolism was studied by measuring isocitrate dehydrogenase (ICDH, EC 1.1.1.42) and NADP activity according to Briand et al. [5]. The two protocols were described in detail by Jurie et al. [20]. Enzyme activities were expressed in $\mu$ mole per min per gram of wet muscle.

\subsubsection{Total collagen assay and collagen in the insoluble part}

To estimate total collagen, total hydroxyproline (OH-Prol) content was measured as previously described by Listrat et al. [21]. Collagen in the insoluble part was determined according to a procedure adapted from Hill [17]. Lyophilised muscle powder $(100 \mathrm{mg})$ was rehydrated for one hour in $10 \mathrm{ml}$ of buffer $(0.23 \mathrm{M} \mathrm{NaCl}, 25 \mathrm{mM}$ Tris- $\mathrm{HCl}, \mathrm{pH} 7.4$ ) before being placed in a $75{ }^{\circ} \mathrm{C}$ water bath for one hour. After centrifugation at $4000 \mathrm{~g}$ for $20 \mathrm{~min}$ at room 
temperature, the pellet which corresponded to the heat-insoluble collagen was retained and $\mathrm{OH}-$ prol content was measured [21]. The data are represented as means of triplicates and are expressed, for total collagen, in $\mu \mathrm{g}$ of $\mathrm{OH}$-prol per mg of dry matter and for insoluble collagen as percentage of $\mathrm{OH}$-prol in the insoluble part per total OH-prol.

\subsection{Statistical analysis}

The feeding data were taken per experimental group and were not the subject of statistical analysis. The other data were analysed using SAS software [29]. The variance analysis was performed using the GLM procedure, normality test was performed using the univariate procedure and the comparison between groups was made using the $t$ test. Results are expressed as means + - SEM.

The statistical analyses showed no effect due to pasture nor any interaction between the type of pasture and the breed with respect to muscular characteristics. Consequently the effect of type of pasture is not discussed in the results.

\section{RESULTS}

\subsection{Growth performance}

Growth performance is shown in Table II and Figure 1. When they arrived, the BA

Table II. Weight and rate of growth of animals.

\begin{tabular}{lccc}
\hline & BA & Charolais & Breed effect \\
\hline Numbers & 22 & 24 & \\
Initial age (months) & $7.5 \pm 0.8$ & $9.4 \pm 0.8$ & \\
Winter 8-12 months & & & \\
$\quad$ Initial weight $(\mathrm{kg})$ & $275 \pm 25$ & $288 \pm 32$ & NS \\
Final weight $(\mathrm{kg})$ & $413 \pm 34$ & $456 \pm 37$ & $p<0.01$ \\
$\quad$ Weight gain $\left(\mathrm{g} \cdot \mathrm{d}^{-1}\right)$ & $1146 \pm 173$ & $1403 \pm 137$ & $p<0.01$ \\
Pasture 12-20 months & & & \\
Initial weight $(\mathrm{kg})$ & $385 \pm 28$ & $436 \pm 32$ & $p<0.01$ \\
Final weight $(\mathrm{kg})$ & $524 \pm 41$ & $588 \pm 40$ & $p<0.01$ \\
Weight gain $\left(\mathrm{g} \cdot \mathrm{d}^{-1}\right)$ & $692 \pm 182$ & $752 \pm 151$ & $\mathrm{NS}$ \\
Winter 20-24 months & & & \\
Initial weight $(\mathrm{kg})$ & $542 \pm 42$ & $612 \pm 44$ & $p<0.01$ \\
Final weight $(\mathrm{kg})$ & $609 \pm 38$ & $680 \pm 49$ & $p<0.01$ \\
Weight gain $\left(\mathrm{g} \cdot \mathrm{d}^{-1}\right)$ & $651 \pm 150$ & $658 \pm 159$ & $\mathrm{NS}$ \\
Pasture 24-29 months & & & \\
Initial weight $(\mathrm{kg})$ & $611 \pm 38$ & $680 \pm 47$ & $p<0.01$ \\
Final weight $(\mathrm{kg})$ & $721 \pm 42$ & $785 \pm 55$ & $p<0.01$ \\
Weight gain $\left(\mathrm{g} \cdot \mathrm{d}^{-1}\right)$ & $746 \pm 166$ & $712 \pm 180$ & $p<0.01$ \\
Finishing & & & \\
Initial weight $(\mathrm{kg})$ & & & \\
Initial state of fattening (marked out of 5) & $2.7 \pm 0.4$ & $3.1 \pm 0.3$ & $p<0.01$ \\
Final weight $(\mathrm{kg})$ & $811 \pm 30$ & $825 \pm 55$ & NS \\
Final state of fattening (marked out of 5) & $2.9 \pm 0.4$ & $3.4 \pm 0.3$ & $p<0.01$ \\
Weight gain $\left(\mathrm{g} \cdot \mathrm{d}^{-1}\right.$ ) & $1384 \pm 326$ & $1555 \pm 732$ & NS \\
Final age $(\mathrm{months})$ & $31.1 \pm 0.9$ & $31.7 \pm 1.0$ & $p<0.01$ \\
Duration of finishing (days) & $62 \pm 15$ & $22 \pm 12$ & $p<0.01$ \\
\hline & & &
\end{tabular}


male calves were about 2 months younger than the charolais animals, and weighed $13 \mathrm{~kg}$ less but the weight difference was not significant.

During the first winter when the animals were aged between 8 and 12 months and were fed ad libitum with maize silage, the BA animals grew distinctly slower than the Charolais.

When put out to pasture the BA animals lost $30 \mathrm{~kg}$ as compared with $20 \mathrm{~kg}$ for the Charolais over the first 15 days at grass. During the pasturing season, the BA growth rate was $8 \%$ below that of the Charolais (Tab. II).

During the following winter, between 20 and 24 months old, the animals showed the same growth rate in each breed. For the last season of grazing, between 24 and 29 months old, with slightly higher growth rates the BA were lighter and thinner on entrance to the cowshed for finishing.

At the end of this finishing period of different duration (respectively for the BA and the Charolais, $62 \mathrm{~d}$ vs. $22 \mathrm{~d}$ ) the animals were slaughtered at the same weight $(818 \mathrm{~kg})$, the BA remaining thinner.

\subsection{Winter feed consumption (Tab. III)}

During the first winter, with a diet ad libitum based on corn and hay silage, the BA ingested $5.78 \mathrm{~kg} \mathrm{DM} \cdot$ day $^{-1}$, i.e. $1.7 \mathrm{~kg} \mathrm{DM}$ per $100 \mathrm{~kg}$ of live weight. In the same conditions, the Charolais ingested $7.52 \mathrm{~kg} \mathrm{DM}$ per day, i.e. $2.03 \mathrm{~kg} \mathrm{DM}$ for $100 \mathrm{~kg}$ of live weight.

During the 2nd winter, the animals were fed with grass silage given ad libitum. The BA steers ingested $8.35 \mathrm{~kg}$ of DM compared to $8.66 \mathrm{~kg}$ for the Charolais. The energy quantities ingested corresponded to the recommended intakes for the weights and the weight gains made, however, the nitrogen evaluation showed that the intakes were clearly lower than the recommendations ( $-200 \mathrm{~g}$ of PDI per animal and per day), i.e. $-29 \%$.

\subsection{Activities during grazing (Tab. IV)}

The animals of each breed grazed for the same time (380 minutes \pm 80 ). The nature of the pasture type influenced this criteria, as the animals on fescue grazed 50 more minutes than those on perennial rye grass and wild white clover. Between the beginning and the end of their presence on a plot, the grazing was extended by one hour to allow for the reduced height and density of sward.

At grazing, no factor modified significantly the bite frequency. The animals made 52 bites per minutes on average, whatever the breed, the type of pasture and its height and density. On the other hand, the differences between animals were significant and recurred every day of observation, with a hierarchy between animals remaining exactly the same in each group.

During a day with 6 hours and 20 minutes of pasture, the animals made 20000 bites whatever the breed considered. However this number varied according to the height and density of sward/pasture. Indeed 3000 further bites were made between the beginning and the end of a plot, on the fescue or on the rye grass or wild white clover grasslands. In addition, the type of pasture influenced the grazing time and consequently the total number of bites in 24 hours. Thus the animals spent more time grazing the fescue than the rye grass-white clover mixture. So with the same number of bites per minute they probably ingested more dry matter with the fescue each day, than with the rye grass-white clover mixture.

\subsection{Body characteristics at slaughter (Tab. V)}

Slaughtered at the same body mass (live weight without digestive contents), the BA had a real output (carcass weight divided by body mass) of $70.3 \%$. This real output was 1.6 points higher than for the Charolais $(p<0.001)$. The muscle output $(68.7 \%)$ of the BA was also higher, i.e. 4.4 points 
higher than for the Charolais, which means they had an extra $9 \%$ of muscle $(p<0.001)$

With a higher muscle weight, the BA associated a lower weight of fat deposits in the carcass (4 points meaning $17 \mathrm{~kg}$ less), although the fat deposits in the 5th quarter differed little. This lower proportion of fat was observed in vivo prior to slaughter and right from the end of pasturing at the beginning of the fattening period. It represents a lower proportion of sub-cutaneous fat, assessed by palpation.

\subsection{Metabolic and contractile type of muscle fibres (Tab. VI)}

ST muscle of BA steers presented a significantly higher LDH activity than that of the Charolais $(p<0.001)$ and conversely, a very significantly lower ICDH activity $(p<0.001)$. These differences were accompanied by a greater proportion of rapid glycolytic type fibres (IIB) $(p<0.01)$ and a lower proportion of slow oxidative type (I) fibres $(p<0.01)$. For the rapid oxido-glycolytic

Table III. Quantity of foodstuffs ingested and nutritional value of rations during the winter periods.

\begin{tabular}{|c|c|c|}
\hline & BA & Charolais \\
\hline & \multicolumn{2}{|c|}{ Winter between 8 and 12 months of age } \\
\hline \multicolumn{3}{|c|}{ Dry matter $(\mathrm{DM})$ ingested per day $(\mathrm{kg})$ : } \\
\hline Maize silage & 4.78 & 6.29 \\
\hline Hay & 0.13 & 0.10 \\
\hline Rape seed oil cake & 0.87 & 1.13 \\
\hline MVS & 0.09 & 0.09 \\
\hline Total & 5.78 & 7.52 \\
\hline kg DM per 100 kg live weight & 1.70 & 2.03 \\
\hline Net energy ingested (UFV) & 5.12 & 6.67 \\
\hline $\operatorname{PDIN}(\mathrm{g})$ & 433 & 559 \\
\hline PDIE (g) & 462 & 599 \\
\hline \multicolumn{3}{|l|}{ Recommended intake $^{1}$ : } \\
\hline Net energy ingested (UFV) & 5.26 & 6.20 \\
\hline \multirow[t]{2}{*}{ PDI $(g)$} & 567 & 666 \\
\hline & \multicolumn{2}{|c|}{ Winter between 20 and 24 months of age } \\
\hline \multicolumn{3}{|c|}{ Dry matter $(\mathrm{DM})$ ingested per day $(\mathrm{kg})$ : } \\
\hline Grass silage & 8.26 & 9.65 \\
\hline MVS & 0.09 & 0.09 \\
\hline Total & 8.35 & 8.66 \\
\hline kg DMS per $100 \mathrm{~kg}$ live weight & 1.45 & 1.49 \\
\hline UFL & 6.38 & 7.36 \\
\hline PDIN (g) & 531 & 611 \\
\hline PDIE (g) & 435 & 502 \\
\hline \multicolumn{3}{|l|}{ Recommended intake ${ }^{1}$ : } \\
\hline UFL & 6.40 & 7.18 \\
\hline PDI (g) & 623 & 691 \\
\hline
\end{tabular}

MVS: Mineral and Vitamin Supplement.

${ }^{1}$ The recommended intakes are calculated on the basis of performance noted and INRA tables [19].

UFL or UFV: Net energy for maintenance and gain. Values expressed in milk feed units (Unités Fourragères Lait) or in meat feed units (Unités Fourragères Viande).

Proteins truly Digestible in the small Intestine allowed by the Nitrogen (PDIN) or energy (PDIE) level [19]. 
Table IV. Activity at pasture.

$n$ Charolais BA Breed effect RGA + C Fescue Effect of type On entry On exit Effect of density

of pasture to plot from plot and height of sward

\begin{tabular}{|c|c|c|c|c|c|c|c|c|c|c|}
\hline Time at pasture (min) & 24 & $\begin{array}{l}380 \\
\pm 87\end{array}$ & $\begin{array}{l}388 \\
\pm 78\end{array}$ & NS & $\begin{array}{r}359 \\
\pm 79\end{array}$ & $\begin{array}{l}408 \\
\pm 79\end{array}$ & $p<0.01$ & $\begin{array}{r}353 \\
\pm 68\end{array}$ & $\begin{array}{l}415 \\
\pm 84\end{array}$ & $p<0.01$ \\
\hline Bite rate (No./min) & 12 & $\begin{array}{l}52.1 \\
\pm 6.6\end{array}$ & $\begin{array}{l}51.8 \\
\pm 6.7\end{array}$ & NS & $\begin{array}{r}51.2 \\
\pm 5.0\end{array}$ & $\begin{array}{r}52.7 \\
\pm 7.9\end{array}$ & NS & $\begin{array}{r}52.2 \\
\pm 7.2\end{array}$ & $\begin{array}{r}51.7 \\
\pm 6.1\end{array}$ & NS \\
\hline Number of bites in 24 hours & 12 & $\begin{array}{r}19830 \\
\pm 5635\end{array}$ & $\begin{array}{l}20007 \\
\pm 4599\end{array}$ & NS & $\begin{array}{r}18318 \\
\pm 4335\end{array}$ & $\begin{array}{r}21519 \\
\pm 5369\end{array}$ & $p<0.01$ & $\begin{array}{r}18255 \\
\pm 3925\end{array}$ & $\begin{array}{r}21582 \\
\pm 5639\end{array}$ & $p<0.01$ \\
\hline
\end{tabular}

RGA: Perennial rye grass. C: White clover. BA: Blonde d'Aquitaine.

Table V. Body characteristics at slaughter

\begin{tabular}{|c|c|c|c|}
\hline & $\mathrm{BA}$ & Charolais & Breed effect \\
\hline Number & 19 & 21 & \\
\hline Weight at slaughter $(\mathrm{kg})$ & $811 \pm 30$ & $825 \pm 55$ & NS \\
\hline Fattening mark at slaughter & $2.9 \pm 0.3$ & $3.4 \pm 0.3$ & $p<0.01$ \\
\hline $\begin{array}{l}\text { Live weight empty (LWE) (kg) } \\
\text { Hot carcass weight (WCW) (kg) } \\
\text { Actual yield (WCW/LWE) (\%) }\end{array}$ & $\begin{array}{c}694 \pm 22 \\
487 \pm 21 \\
70.3 \pm 1.0\end{array}$ & $\begin{array}{l}696 \pm 48 \\
478 \pm 38 \\
68.7 \pm 1.5\end{array}$ & $\begin{array}{l}\text { NS } \\
\text { NS } \\
p<0.01\end{array}$ \\
\hline $\begin{array}{l}\text { Carcass composition }(\mathrm{kg})^{*} \\
\text { Muscle } \\
\text { Fatty tissues } \\
\text { Bone }\end{array}$ & $\begin{array}{c}355 \pm 17 \\
80 \pm 7 \\
72 \pm 4\end{array}$ & $\begin{array}{l}308 \pm 30 \\
97 \pm 8 \\
73 \pm 5\end{array}$ & $\begin{array}{l}p<0.01 \\
p<0.01 \\
\quad \mathrm{NS}\end{array}$ \\
\hline $\begin{array}{l}\text { Fatty tissue deposits (kg) } \\
\text { Fifth quarter } \\
\text { Total fatty tissue (TFT) } \\
\text { TFT/LWE }(\%)\end{array}$ & $\begin{array}{l}26.1 \pm 3.3 \\
106 \pm 9 \\
15.3 \pm 1.2\end{array}$ & $\begin{array}{c}27.8 \pm 5.9 \\
125 \pm 13 \\
18.0 \pm 1.7\end{array}$ & $\begin{array}{c}\text { NS } \\
p<0.01 \\
p<0.01\end{array}$ \\
\hline
\end{tabular}


Table VI. Effect of breed on enzyme activities on the percentage and cross-sectional area of different fibre types and on the collagen in the Semitendinosus muscle of cattle.

\begin{tabular}{|c|c|c|c|c|}
\hline \multicolumn{2}{|c|}{ Mesures } & BA & Charolais & Breed effect \\
\hline \multicolumn{5}{|c|}{ Enzyme activities $\left(\mu \mathrm{mol} \cdot \mathrm{min}^{-1} \cdot \mathrm{g}^{-1}\right)$} \\
\hline \multicolumn{2}{|c|}{$\begin{array}{l}\text { ICDH } \\
\text { LDH }\end{array}$} & $\begin{aligned} 1.11 & \pm 0.08 \\
1497 & \pm 80\end{aligned}$ & $\begin{array}{l}1.55 \pm 0.05 \\
1351 \pm 95\end{array}$ & $\begin{array}{l}p<0.001 \\
p<0.001\end{array}$ \\
\hline \multicolumn{5}{|c|}{ Proportions $(\%)$ and cross-sectional area of fibres $\left(\mu \mathrm{m}^{2}\right)$} \\
\hline I & $\begin{array}{l}\text { proportion } \\
\text { area }\end{array}$ & $\begin{array}{c}5.8 \pm 1 \\
1919 \pm 146\end{array}$ & $\begin{array}{c}13.7 \pm 0.9 \\
2638 \pm 238\end{array}$ & $\begin{array}{c}p<0.01 \\
p<0.001\end{array}$ \\
\hline & $\begin{array}{l}\text { proportion } \\
\text { area }\end{array}$ & $\begin{array}{c}30.6 \pm 1.4 \\
3008 \pm 220\end{array}$ & $\begin{array}{c}27.6 \pm 1.1 \\
3205 \pm 184\end{array}$ & $\begin{array}{l}\text { NS } \\
\text { NS }\end{array}$ \\
\hline IIB & $\begin{array}{l}\text { proportion } \\
\text { area }\end{array}$ & $\begin{array}{c}63.6 \pm 1.6 \\
4939 \pm 347\end{array}$ & $\begin{array}{c}58.8 \pm 1.2 \\
4877 \pm 264\end{array}$ & $\begin{array}{c}p<0.01 \\
\text { NS }\end{array}$ \\
\hline \multicolumn{2}{|c|}{ Total collagen $\left(\mu \mathrm{g}\right.$ OH-prol $\left.\cdot \mathrm{mg}^{-1} \mathrm{DM}\right)$} & $3.74 \pm 0.3$ & $5.18 \pm 0.6$ & $p<0.01$ \\
\hline \multicolumn{2}{|c|}{ Proportion of insoluble collagen (\%) } & $83.0 \pm 3.0$ & $83.9 \pm 3.1$ & NS \\
\hline
\end{tabular}

BA: Blonde d'Aquitaine. 
fibres no difference was found. The BA oxidative fibres (type I) were smaller than those of the Charolais $(p<0.01)$ but the other types of fibre showed no difference in size.

\subsection{Total collagen content and insoluble collagen proportion (Tab. VI)}

The BA ST muscle contained less total collagen than that of Charolais $(p<0.01)$. However there was no significant difference between the breeds in the proportion of insoluble collagen.

\section{DISCUSSION}

\subsection{Zootechnical performances}

During the first winter the BA voluntarily ate $1.7 \mathrm{~kg}$ less dry matter than the Charolais, particularly in the form of maize silage, which means $0.3 \mathrm{~kg}$ per $100 \mathrm{~kg}$ live weight less as a result of a lower capacity for ingestion. This is no doubt due to the fact that they were younger, had a shorter period of pasture with their mother and perhaps a digestive tract which was slower to mature, although no significant difference was found in this respect at slaughter (result not published). BA bull calves were found to have a lower capacity for ingestion compared with charolais cross salers bull calves in a study by Didier et al. [10]. Subsequently the energy quantities ingested were lower, below those recommended for beef breeds, unlike the charolais animals. This resulted in slower growth and a lower weight when put out to pasture, with a consequent delay in the start of growth, just as we found with the normandy breed [11]. The animals showed a higher capacity for ingestion than that noted for late-maturing beef breeds [12]: $+8 \%$ for the Charolais versus $+5 \%$ for the BA, which could be explained by an overestimation of the bulk ratio applied to the grass silage used. The energy evaluation was balanced, but the nitrogen evaluation showed an intake distinctly below the recommendations ( -100 to $-200 \mathrm{~g}$ PDI per animal and per day), meaning a lower nitrogen requirement than that allowed for by the INRA recommendations, particularly for the BA, as observed in bull calves by Didier et al. [10].

Subsequently the steers of this breed showed identical if not greater growth rates during the 2nd pasture season, compared with the charolais steers. However, they did not make up for the difference in weight when first put out to pasture. At $698 \mathrm{~kg}$ lower live weight at the beginning of fattening at the trough, the BA stayed 40 days longer in finishing before being slaughtered at a slightly lower live weight $(14 \mathrm{~kg}$, non significant) than the Charolais. These results agree with those obtained by Gillard et al. [14] who observed that the lower live weight at slaughter of BA crossbreed compared with charolais animals was due essentially to a lower growth rate between birth and weaning.

Although a difference in ingestion was found with a diet based on maize silage during the winter and the finishing period, the zootechnical performances at pasture, in particular during the second season at grass, together with the measurement of behaviour at pasture showed no difference in capability between the two breeds being studied, whatever the forage situation in question (type of vegetation, cycle, degree of defoliation). Note however that it was not possible to measure the quantities of grass ingested at pasture.

On the other hand, at slaughter the BA had a higher yield for carcass and muscle (respectively, +2 and +4 points), which meant $9 \%$ extra muscle weight for the same body mass. These findings are different to those of Gillard et al. [14] who did not observe any difference in carcass and muscle yield when comparing BA crossbred steers and charolais or maine-anjou animals. They complete those of Morand [22] who showed a clearly higher meat yield 
for BA bull calves (respectively 4 and 5 points) compared with charolais and maineanjou bull calves. Even though they were fed for 40 extra days at finishing, the BA were less fat, showing less aptitude to fatten at pasture. This was not observed by Gillard et al. [14] with BA crossbred steers.

\subsection{Muscle characteristics}

ST is a mixed muscle in terms of muscle fibre composition, and an intermediate muscle compared to all the others in terms of collagen content. It gives meat for grilling and is thus advantageous from the economic point of view. In BA animals the ST muscle showed a more glycolytic metabolism, with a higher proportion of type IIB fibres than the same muscle in charolais animals. Collagen is responsible for conjunctive hardness in meat. It transforms only slightly during maturing, if at all. It has an effect due to its quantity, and also its degree of solubility $[4,7,21]$. Various studies have shown that the richer a muscle is in collagen, the less tender the meat [25-27]. In the present study, we observed that the ST muscle in BA animals contained less collagen than that from charolais animals, although there was no difference in terms of collagen solubility.

It is known that the type of fibre plays an important part in the speed of maturing. With a given length of hanging, muscles with a high proportion of type IIB fibres should be more tender because they should mature more quickly than muscles containing a higher proportion of type I fibres [30, 31]. However, a glycolytic muscle metabolism is often associated with the presence of less intramuscular fat and myoglobin, which results in less flavour [31] and a paler colour [27]. Unfortunately none of these characteristics was measured. So, compared to the Charolais, the BA presented characteristics for ST muscle (with more glycolytic metabolism type IIB fibres and less collagen) which should enable them to provide more tender meat than the Charolais. Excellent meat tenderness from male BA animals was already observed by Morand [22]. The author of the present study submitted 3 bull calf muscles to a tasting panel, and found that the tenderness marks given for these muscles were significantly higher than those obtained for the same muscles from normandy breed milk cows, which were even so considered to be satisfactorily tender by the panel.

Together with these muscular characteristics there is a better yield both for carcass and muscle, placing them close to doublemuscled type animals $[3,6,18]$ and charolais animals selected for high muscular growth [26].

The BA animals also present another special point. Although none were included in this study, this breed does include certain animals with the double-muscle phenotype, meaning hypertrophy of certain superficial muscles. In charolais animals this phenotype is due to mutation of the myostatin gene. This mutation has not been identified in the BA breed [15].

\section{CONCLUSION}

These results demonstrate a certain number of characteristics specific to the BA breed. Due to a lower ingestion capability and better carcass and muscle yield, the BA animals studies made better use of the forage they were given than the charolais animals with which they were compared. In addition they supplied muscles with characteristics which appeared liable to give tender meat: a more glycolytic metabolism, a higher proportion of type IIB fibres and a lower collagen content. These characteristics are comparable to those of breeds presenting muscle hypertrophy (Picard et al., manuscript currently being prepared). It would be desirable to complete these studies by other measurements (tasting test, measurement of fibre 
shear strength, ...) to confirm whether or not the muscular characteristics found are correlated in positive fashion with meat tenderness.

\section{ACKNOWLEDGEMENT}

The authors would like to thank the staff at the Pin au Haras INRA establishment, R. Jailler and the staff at the INRA slaughterhouse at Theix, together with the technicians at the "Laboratoire Croissance et Métabolismes des Herbivores".

\section{REFERENCES}

[1] Agabriel J., Giraud J.-M., Petit M., Détermination et utilisation de la note d'état d'engraissement en élevage allaitant, Bull. Tech. CRZV Theix 66 (1986) 43-50.

[2] Ansay M., Individualité musculaire chez le bovin : étude de l'équipement enzymatique de quelques muscles, Ann. Biol. Anim. Bioch. Biophys. 14 (1974) 471-486.

[3] Bailey A.J., Enser M.B., Dransfield E., Restall D.J., Avery N.C., Muscle and adipose tissue from normal and double muscled cattle: collagen types, muscle fibre diameter, fat cell size and fatty acid composition and organoleptic properties, in: King J.W.B., Ménissier F. (Eds.), Muscle hypertrophy of genetic origin and its use to improve beef production, London, 1982 pp. 178-204.

[4] Berry B.W., Smith G.C., Carpenter Z.L., Relationships of certain muscle, cartilage and bone traits to tenderness of the beef longissimus, J. Food Sci. 39 (1974) 819-824.

[5] Briand M., Talmant A., Briand Y., Monin G., Durand R., Metabolic types of muscle in sheep: I. Myosin ATPase, glycolytic, and mitochondrial enzyme activities, Eur. J. Appl. Physiol. 46 (1981) 347-358.

[6] Clinquart A., Hornick J.L., Van Eenaeme C., Istasse L., Influence du caractère culard sur la production et la qualité de la viande des bovins Blanc, Bleu, Belge, INRA Prod. Anim. 11 (1998) 285-297.

[7] Cross H.R., Carpenter Z.L., Smith G.C., Effect of intramuscular collagen and elastin upon bovine muscle tenderness, J. Food Sci. 38 (1973) 998-1003.

[8] D'Hour P., Petit M., Garel J.P., Mante A., Variations in grazing behaviour of Salers and Limousin heifers during time spent in the paddock in a rotational system, Ann. Zootech. 43 (1994) 289
[9] D'Hour P., Petit M., Michat G., Diurnal variations in the bite rate of cattle at pasture, Ann. Zootech. 43 (1994) (Suppl. 1) S37.

[10] Didier G., Cathala P., Bonnefoy J., Compterendu de 5 essais sur l'engraissement de taurillons de race Blonde d'Aquitaine C.E.E.S.O. Soual, 1993.

[11] Dozias D., Micol D., Peccatte J.-R., Modalités de production de bœufs laitiers de 30 mois à l'herbe, Ann. Zootech. 44 (1995) 229-246.

[12] Erlinger L., Tolleson D.R., Brown C.J., Comparison of bite size, biting rate and grazing time of beef heifers from herds distinguished by nature, size and rate maturity, J. Anim. Prod. 68 (1990) 3578-3587.

[13] Ferrer Cazcarra R., Petit M., The effect of winter feeding level on subsequent grazing behaviour and herbage intake of Charolais heifers, J. Anim. Sci. 61 (1995) 211-217.

[14] Gillard P., Leconte D., Chambeyron J.J., Frebling J., Production de bœufs de différents types génétiques finis à l'auge à 30 mois (bilan de 7 années), Bull. Tech. CRZV Theix 65 (1986) 31-39.

[15] Grobet L., Poncelet D., Royo L.J., Brouwers B., Pirottin D., Michaux C., Ménissier F., Zanotti M., Dunner S., Georges M., Molecular definition of an allelic series of mutations disrupting the myostatin function and causing doublemuscling in cattle, Mam. Gen. 9 (1998) 210-213.

[16] Guth L., Samaha F.J., Procedure for the histochemical demonstration of actomyosin ATPase, Exp. Neurol. 28 (1970) 365-367.

[17] Hill F., The solubility of intramuscular collagen in meat animals of various ages, J. Food Sci. 31 (1966) 161-166.

[18] Holmes J.H.G., Ashmore C.R., A histochemical study of muscle fiber types and size in norma and double muscled cattle, Growth 36 (1972) 351-360.

[19] INRA, Alimentation des bovins, ovins et caprins, INRA Paris, 1988, 471 p.

[20] Jurie C., Robelin J., Picard B., Geay Y., Postnatal changes in the biological characteristics of Semitendinosus muscle in male Limousin cattle, Meat Sci. 41 (1995) 125-132.

[21] Listrat A., Rakadjiyski N., Jurie C., Picard B. Touraille C., Geay Y., Effect of the diet on muscle characteristics and meat palatability of growing Salers bulls, Meat Sci. 53 (1999) 115-124.

[22] Morand J., Valeur bouchère du taurillon BA, Viande Prod. Carnés 6 (1985) 47-52.

[23] Pearse A.G.E., Histochemistry: Theoretical and Applied, 2nd ed., Churchill J.A. (Ed.), London, Vol. 2, 1968, p. 1342.

[24] Peter J.B., Barnard R.J., Edgerton V.R., Gillespie C.A., Stempel K.E., Metabolic profiles of three fiber types of skeletal muscle in guinea pigs and rabbits, Biochemistry 11 (1972) 2627-2633. 
[25] Reagan J.O., Carpenter Z.L., Smith G.C. Chronological age, collagen solubility, sarcomere length and beef tenderness, J. Anim. Sci. 37 (1973) 270 (Abstract).

[26] Renand G., Berge P., Picard B., Robelin J., Geay Y., Krauss D., Ménissier F., Genetic parameters of beef production and meat quality traits of young Charolais bulls progeny of divergently selected sires, Proc. 5th world congress in genetics applied to livestock production, Vol. 19, Guelph Canada, 1994, pp. 446-449.

[27] Renerre M., Labadie J., Fresh red meat packaging and meat quality, Review paper Proceeding of the International Congress on Meat
Science and Technology, 39th ICoMST, Calgary, AB, Canada 8 (1993) 361-389.

[28] Robelin J., Geay Y., Estimation de la composition de la carcasse des taurillons à partir de la composition de la $6^{\mathrm{e}}$ côte, Bull. Tech. CRZV Theix 22 (1975) 41-44.

[29] S.A.S., Stat. Guide for personal computer (Version 6 Ed.), S.A.S. Inst. Inc., Cary, NC, 1985.

[30] Touraille C., Influence des caractéristiques musculaires sur les qualités organoleptiques des viandes, Renc. Rech. Rum. 1 (1994) 169-176.

[31] Valin C., Différenciation du tissu musculaire. Conséquences technologiques pour la filière viande, Reprod. Nutr. Dev. 28 (1988) 845-856. 